\title{
COMMENTARIES
}

\section{EXECUTIVE PRIVILEGES AND IMMUNITIES: THE NIXON AND CLINTON CASES}

\author{
Akhil Reed Amar* \& Neal Kumar Katyal**
}

In 1978, Ernest Fitzgerald sued Richard Nixon, and in I994, Paula Jones sued Bill Clinton. In a landmark but closely divided I982 opinion, Nixon v. Fitzgerald, the Supreme Court sided with Nixon and against Fitzgerald. ${ }^{1}$ What does this mean for Jones and Clinton today?2 Ed Meese speaks for many when he insists that Nixon protects Presidents only for presidential conduct and that extending immunity to Clinton's pre-presidential conduct would be a huge and unprincipled stretch that would place Bill Clinton above the law. ${ }^{3}$ Other commentators aren't so sure that Nixon itself was rightly decided but are sure that Clinton's claim is much weaker. Terry Eastland has argued

* Southmayd Professor, Yale Law School.

** Student, Yale Law School. At the time this Commentary was written, Mr. Katyal was working in the Office of the Solicitor General, United States Department of Justice. He had no involvement with the brief filed by the Solicitor General in the Paula Corbin Jones litigation.

An earlier version of this Commentary was presented on September 22, 1994 as the Hardy Cross Dillard Lecture at the University of Virginia School of Law; on October I9, I994 as part of the Scholar-in-Residence Program at Hofstra University School of Law; and on October 26, I994 as part of the Edward L. Barrett, Jr. Lecture Program at the University of California at Davis School of Law. For helpful comments on earlier drafts, we thank Bruce Ackerman, Vik Amar, Ian Ayres, Jack Balkin, Susan Low Bloch, Steve Calabresi, Betsy Cavendish, Owen Fiss, Joseph Goldstein, Harold Koh, John Langbein, Burke Marshall, Vinita Parkash, Mike Paulsen, Jeff Rosen, Jed Rubenfeld, Peter Swire, Laurence Tribe, and Eugene Volokh.

1457 U.S. 73I (1982). The suit alleged that Nixon had unlawfully fired Fitzgerald in retaliation for his testimony before Congress about military aircraft cost overruns.

2 Jones's suit raises four claims. She asserts violations of 42 U.S.C. $\$ \S 1983$ and 1985 that stem from Clinton's alleged conduct while Governor of Arkansas, a state law intentional infliction of emotional distress claim that arises from the same alleged action, and a state law claim alleging that Clinton and his aides defamed her while he was President. See Jones v. Clinton, Complaint, Civ. No. LR-C-94-29o (E.D. Ark. May 6, 1994).

Editors' Note: As this Commentary went to press, the U.S. District Court for the Eastern District of Arkansas ruled that no trial should occur until after the end of President Clinton's tenure, but that pretrial discovery could proceed now. This ruling may be appealed. See Jones v. Clinton, 1994 WL 721905 at $*_{7-* 8}$ (E.D. Ark. Dec. 28, 1994).

3 Nightline: Presidential Immunity (ABC television broadcast, June 13, 1994) (transcript on file with the Harvard Law School Library); Crossfire: Justice Delayed for the President? (CNN television broadcast, May 25, 1994) (transcript on file with the Harvard Law School Library); Morning Edition: Sexual Harassment Suit Questions Presidential Immunity (National Public Radio broadcast, June 15, 1994) (transcript on file with the Harvard Law School Library). 
that, if you reject Nixon's immunity claim, you presumably must reject Clinton's a fortiori. ${ }^{4}$

We will show that all of this is dead wrong. Bill Clinton's claim for immunity is actually much stronger than Richard Nixon's - supported by crisper arguments from constitutional text and structure, by more historical evidence from the Founding and early Republic, and by better modern-day policy arguments. Nixon sought absolute and permanent immunity from a civil damage action after he left office; Clinton seeks only temporary immunity from litigating a civil damage suit while he serves as President. We will show that the Arrest Clause of Article I, Section 6 and the democratic structural principles underlying this Clause cast light on Article II, and provide a sturdy constitutional basis for temporary presidential immunity. In the process of elaborating the best argument for Clinton, we will also show how all nine Justices in Nixon missed the point and in particular misread a key quote from the great Justice Joseph Story. We will outline a new theory of limited executive immunity that protects a sitting President and (most importantly) the American people he serves, yet does not put the President above the law, as Nixon did, despite the Court's protestations to the contrary.

\section{UNTANGLING ImMUNity}

The Constitution nowhere explicitly describes what litigation immunity, if any, the President merits by dint of his unique constitutional role. The document does, however, explicitly describe certain governmental immunities. Article I, Section 6 provides that:

The Senators and Representatives . . . shall in all Cases, except Treason,

Felony and Breach of the Peace, be privileged from Arrest during their Attendance at the Session of their respective Houses, and in going to and returning from the same; and for any Speech or Debate in either House, they shall not be questioned in any other Place. ${ }^{5}$

\section{A. Expressio Unius?}

At first glance, this Clause seems to be powerful ammunition for the presidential immunity skeptics. After all, no such explicit provision exists for the President. Didn't our Founders clearly mean to say, by expressio unius, ${ }^{6}$ that the President is not entitled to immunity?

4 See Terry Eastland, No Immunity for Clinton from Paula Jones's Charges, Wall St. J., June 8, I 994 , at AI7.

5 U.S. Const. art. I, $\S 6$.

6 The legal maxim expressio unius est exclusio alterius means that the expression of one thing (here, congressional arrest and speech or debate immunities) by implication excludes other things (here, presidential or judicial immunities, or other congressional immunities). The maxim is in many contexts sound, but as we shall show, must not be applied clumsily or mechanically. 
But this expressio unius argument is far weaker than it looks. In light of the explicit reference to "Speech or Debate" in Article I, let's look at the Constitution's other free speech clause: "Congress shall make no law .... abridging the freedom of speech." By similar expressio unius logic, shall we say that the First Amendment limits only Congress - that the President may propound censorship edicts and the federal courts may issue gag rules without regard to First Amendment principles? Or shall we say under expressio unius that, in the absence of the First Amendment, only Senators and Representatives, but not ordinary citizens, would enjoy constitutional freedom of speech or debate?

Surely not. Even if the First Amendment did not exist, the Constitution's overall structure and its commitment to democratic self-government would require a broad freedom of speech and debate for citizens on issues of public concern. ${ }^{8}$ Article I, Section 6 had its roots in England, where Parliament was sovereign, and, as a self-governing body, needed wide freedom to debate public issues. ${ }^{9}$ (The very word Parliament - from the French parler, to speak - emphasizes the central role of speech and debate.) But in America, "We the People" are sovereign and must enjoy an analogous (though not necessarily identical) freedom of speech and debate on public, political issues. ${ }^{10}$ So, if the First Amendment had never been adopted, we clearly would not read Article I, Section 6, by expressio unius, to say that Senators and Representatives enjoy freedom of speech, but citizens do not. Even if the scope of freedom were only analogous and not identical, ${ }^{11}$ it would be odd to say that Section 6 meant that no other immunities for speech existed; that such immunities were unconstitutional or extraconstitutional; or that to recognize such immunities in the teeth of the words inside Section 6 and the silence outside it would be to "make things up."

So too with the words of the First Amendment explicitly prohibiting only congressional censorship. The general theory of popular sovereignty frowns on all suppressions of citizens' free speech, whether by

7 U.S. CoNsT. amend. I. On the connection between these two clauses, see Akhil Reed Amar, The Bill of Rights as a Constitution, I00 YALE L.J. II3I, II5I (I99I) [hereinafter Bill of Rights]; Akhil Reed Amar, The Case of the Missing Amendments: R.A.V. v. City of St. Paul, 106 HARV. L. REV. I24, I4I (I992); Alexander Meiklejohn, The First Amendment Is an Absolute, I96I SUP. CT. REV. 245, 255-56.

8 See Charles L. Black, Jr., Structure and Relationship in Constitutional Law 35-50 (i969); Alexander Meiklejohn, Political Freedom: The Constitutional Powers OF THE PEOPLE IOI-24 (ig6o).

9 See Akhil Reed Amar, The Bill of Rights and the Fourteenth Amendment, ior YALE L.J. I I93, 1267 (I992) [hereinafter Fourteenth Amendment].

10 See id. The citizen's freedom of speech might be only analogous rather than identical in that it might be, say, less absolute than the legislator's freedom.

11 See, e.g., New York Times Co. v. Sullivan, 376 U.S. 254, 269-80 (I964) (recognizing broad, though not absolute, freedom of speech for citizens on issues of public concern). 
congressional law, presidential edict, or judicial decree. ${ }^{12}$ If the President and federal courts cannot censor citizens with a congressional law, it would be odd to think they can do so without such a law. As with Section 6, the First Amendment is best read not to bar, by expressio unius, citizen freedoms against courts and executives, but rather to invite, by analogy, these unenumerated freedoms implicit in constitutional structure.

It might be argued that the structural reasoning outlined thus far should go no further. Ordinary citizens, the people, may well enjoy unenumerated rights, especially if collective self-government is at stake - this principle is the heart of the Ninth Amendment's affirmation of the people's unenumerated rights. ${ }^{13}$ But, it might be said, unenumerated rights and immunities for governmental officials qua officials are a very different kettle of fish.

Are they really? Always? Consider a federal judge who, in the course of her published judicial opinion, criticizes some person who then brings a libel suit. Our judge is not a Senator or Representative; nor is she speaking "in either House." Must we read Section 6 by expressio unius to imply that our judge enjoys no analogous immunity in performing her public function and doing the people's business? Must we reject even a "constitutional common law" immunity that might be modifiable at the margins by statute? ${ }^{14}$ Surely expressio unius does not require this rigidity; and we should note that, since our nation's Founding, courtroom litigants have enjoyed absolute common law immunity from libel - an immunity arguably constitutionalized in the First Amendment Petition Clause. ${ }^{15}$ Should a judge have less freedom of speech than a litigant? ${ }^{16}$ In a working democracy under law, judges - like Senators, Representatives, and ordinary citizens -

12 See Fourteenth Amendment, supra note 9, at I 273-74.

13 "The enumeration in the Constitution, of certain rights, shall not be construed to deny or disparage others retained by the people." U.S. CoNST. amend. IX. For discussion of the connection between this amendment and collective self-government, see Bill of Rights, cited above in note 7 , at 1200 .

14 "Constitutional common law" here refers to judicially recognized principles that are deducible from the Constitution and designed to implement the Constitution's structure and fill in its gaps but that may nevertheless be subject to statutory modification. We are indebted here to Professor Henry Monaghan. See Henry P. Monaghan, The Supreme Court, 1974 Term - Foreword: Constitutional Common Law, 89 HARV. L. REV. I, IO-I7 (1975).

15 "Congress shall make no law . . . abridging . . . the right of the people . . . to petition the Government for a redress of grievances." U.S. CoNST. amend. I. For an excellent analysis of the protection the Clause was designed to afford litigants, see Eric Schnapper, "Libelous" Petitions for Redress of Grievances - Bad Historiography Makes Worse Law, 74 IowA L. REv. 303, 343-47 (I 989).

16 See Spalding v. Vilas, I6r U.S. 483,497 (1896) ("The authorities . . . are clear, uniform and conclusive, that no action of libel or slander lies, whether against judges, counsel, witnesses or parties, for words written or spoken in the ordinary course of any proceeding before any court or tribunal recognized by law.") (quoting Dawkins v. Lord Rokeby, 8 Q.B. 255, 263 (I873)) (internal quotation marks omitted). 
must have a wide zone of freedom to speak and print. Though the idea is not textually specified in Article I, Section 6, or in Article III, federal judges need absolute or near absolute freedom "of Speech [and] Debate." The very notion of jurisdiction is the power to speak the law, ${ }^{17}$ the power, in John Marshall's immortal phrase, "to say what the law is." 18 To do their job, and to serve the people, judges must be free to enter declaratory judgments of law and fact, judgments that may criticize and anger powerful people. Libel suits against judges interfere with these judicial functions and thus offend our basic constitutional structure. ${ }^{19}$ Regardless of the specific words of Section 6 , its deep structural logic applies to judges as well as legislators.

Now consider a presidential speech (say, on health care legislation pending in Congress) criticizing some group (say, pharmaceutical companies). Is it sensible to argue that, because of expressio unius, the President has no absolute immunity from libel suits? ${ }^{20}$ Even if this immunity is merely a matter of constitutional common law, à la Justice Jackson's Youngstown Category Two ${ }^{21}$ To perform his role in a constitutional democracy, the President - like Senators, Representatives, judges, and ordinary citizens - must be free to speak out on issues of public concern. Indeed, the Constitution explicitly invites the President to make State of the Union speeches, to recommend legisla-

17 See The Federalist No. 8I, at 489 n.* (Alexander Hamilton) (Clinton Rossiter ed., I 96r).

18 Marbury v. Madison, 5 U.S. (I Cranch) I37, I77 (I 803) (emphasis added).

19 Our reasoning on this point tracks the Court's:

[A] series of decisions, uniformly to the same effect, extending from the time of Lord Coke to the present time, established the general proposition that no action will lie against a judge for any acts done or words spoken in his judicial capacity in a court of justice ... "This provision of the law is not for the protection or benefit of a malicious or corrupt judge, but for the benefit of the public, whose interest it is that the judges should be at liberty to exercise their functions with independence and without fear of consequences. ...."

Spalding, I6 I U.S. at 495 (quoting Scott v. Stansfield, 3 L.R.-Ex. 220, 223 (I868)).

20 Consider the following Supreme Court passage:

The law of privilege as a defense by officers of government to civil damage suits for defamation and kindred torts has in large part been of judicial making, although the Constitution itself gives an absolute privilege to members of both Houses of Congress in respect to any speech, debate, vote, report, or action done in session. This Court early held that judges of courts of superior or general authority are absolutely privileged as respects civil suits to recover for actions taken by them in the exercise of their judicial functions, irrespective of the motives with which those acts are alleged to have been performed, Bradley $v$. Fisher, 13 Wall. 335, and that a like immunity extends to other officers of government whose duties are related to the judicial process. Yaselli v. Goff, I 2 F.2d 396, aff'd per curiam, 275 U.S. 503, involving a Special Assistant to the Attorney General. Nor has the privilege been confined to officers of the legislative and judicial branches of the Government and executive officers of the kind involved in Yaselli.

Barr v. Matteo, 360 U.S. 564, 569-70 (1959) (footnotes omitted).

21 In his famous Youngstown concurrence, Justice Jackson outlined three categories of presidential power under the Constitution. See Youngstown Sheet \& Tube Co. v. Sawyer, 343 U.S. 579, 635-38 (1952) (Jackson, J., concurring). Category Two is the functional equivalent of constitutional common law - powers enjoyed by the President under the Constitution that are subject to modification and diminution by congressional statute. 
tion to Congress, and to give a statement of reasons for any veto he hands down. ${ }^{22}$ In performing his high constitutional duties of democratic deliberation, the President may need to speak in ways that criticize and anger powerful people. In this situation too, libel suits would offend the basic structure of the Constitution - for precisely the same reasons as would libel suits against Senators, Representatives, and judges. ${ }^{23}$ It would be downright silly to argue by expressio unius that the President lacks absolute immunity from libel merely because the clauses governing State of the Union messages, recommendations, and vetoes are less explicit than Article I, Section 6; so too, it would be obtuse to recognize absolute immunity for these and only these three communications (under expressio unius) while muzzling the President the rest of the time under penalty of libel lawsuits.

This examination of the Speech or Debate Clause suggests that it is best read not to bar analogous immunities of coordinate branches but rather, if anything, to invite them. And the same holds true, we shall argue, for its companion, the Article I, Section 6 Arrest Clause. If Representatives and Senators should not be impeded ("arrested") by certain private litigation while performing the people's business (while "at session"), this Arrest Clause immunity should not bar, and if anything might invite, analogous immunities for members of coordinate branches while performing the people's business. ${ }^{24}$

22 See U.S. Const. art. II, § 3; art. I, § 7 .

23 Once again, our logic tracks the Court's:

[T] The same general considerations of public policy and convenience which demand for judges of courts of superior jurisdiction immunity from civil suits for damages arising from acts done by them in the course of the performance of their judicial functions, apply to a large extent to official communications made by heads of Executive Departments when engaged in the discharge of duties imposed upon them by law.

Spalding, I6I U.S. at 498 . Consider also the words of Framer James Wilson:

In order to enable and encourage a representative of the publick to discharge his publick trust with firmness and success, it is indispensably necessary, that he should enjoy the fullest liberty of speech, and that he should be protected from the resentment of every one, however powerful, to whom the exercise of that liberty may occasion offence.

James Wilson, Of the Constitutions of the United States and of Pennsylvania - of the Legislative Department, in I THE Works of JAMES WiLson 399, 42 I (Robert G. McCloskey ed., I 967). Wilson saw members of all three branches as representatives of the public. See GoRDON S. Wood, The Creation of the American Republic, 1776-1787, at 597 (1969).

24 We do not here address what, if any, immunities might be appropriate for state officials under the federal Constitution. These immunities raise different issues, because unlike the President and federal judiciary, state officials are not coordinate to Congress.

We also bracket the issue whether state governors should enjoy immunity under state constitutions from state law suits. Although many state constitutions feature clauses for state legislators analogous to Article $I, \S 6$, these constitutions differ from the federal template in two key respects. First, most have historically lacked a strongly unitary executive analogous to the one created by Article II. See Steven G. Calabresi, Some Normative Arguments for the Unitary Executive, 47 ARK. L. REv. (forthcoming 1994); Lawrence Lessig \& Cass R. Sunstein, The President and the Administration, 94 Colum. L. REv. I, 49-50 (1994). Second, in no state does the governor enjoy foreign affairs duties akin to the President's. As will become clear below, the unitary language of 
Nor does any of this analysis violate the language or history of Section 6 or even the formal rule of expressio unius, properly understood. Section 6 nowhere explicitly rejects coordinate immunities statutory, common law, or constitutional. The Framers simply provided more details about the legislature in their prolix Article I than about coordinate branches; so more must be left to sensible structural inference when dealing with the sparser Articles II and III. Textual specification of legislative immunities might have been especially important to some Framers because the practical protection of these immunities would be committed to the other two branches in enforcing and adjudicating concrete cases. Whatever implicit immunities were appropriate for those other branches, it might have been thought, were effectively self-executing - effected by the President's refusal to enforce certain processes against himself, and judges' refusal to entertain certain suits against judges - and so perhaps needed less textual emphasis. $^{25}$ And even under a stringent expressio unius theory, Section 6 could be read merely to set out those governmental immunities that Congress cannot in any way qualify by statute.

Supreme Court case law also emphatically rejects the notion that Section 6 precludes implied immunities for coordinate branches. The Court, for example, has held judges and prosecutors immune for their official duties. ${ }^{26}$ These immunities, it can be argued, do not violate the central tenet of Marbury $v$. Madison, and of Anglo-American law more generally, that "every right ... must have a remedy." 27 Rather, the notion of judicial and prosecutorial immunity may be that one's

Article II and the centrality of the President's foreign affairs duties are key features of our structural analysis of the federal Constitution.

Finally, we do not analyze the issue of what, if any, Arrest Clause-like immunity should be enjoyed by federal judges. Compared with Presidents, see infra pp. 713-14, and members of Congress, see infra pp. $7 \mathrm{II}-\mathrm{I2}$, judges may be more fungible from the perspective of democratic representation and democratic skew. Unlike a President, a judge is not always in session, twentyfour hours a day, every day; and unlike Congress, judges can reschedule their hearings and sessions with relative ease.

25 In the absence of Article I, $\S 6$, legislators could have tried to enact similar statutory immunity, but an unpopular legislative minority might have been at the mercy of a partisan majority. The President might have vetoed such a law, and until such a law passed, members of the First Congress would have been vulnerable. Partisanship was seen as much less likely among a cadre of professional judges. See THE Federalist No. 78, at 470 (Alexander Hamilton) (Clinton Rossiter ed., I96I); Akhil Reed Amar, A Neo-Federalist View of Article III: Separating the Two Tiers of Federal Jurisdiction, 65 B.U. L. REv. 205, 224-28 (1985) [hereinafter Two Tiers].

On the self-protective powers of executive and judicial branches, see THE FEDERALIST No. $5 \mathrm{I}$, at 320-23 (James Madison) (Clinton Rossiter ed., I96I); 3 The Debates, Resolutions, AND Other Proceedings in Convention, on the adoption of the Federal Constitution 245-46 (Jonathan Elliot ed., I830) (remarks of James Wilson at Pennsylvania Ratifying Convention); and Bill of Rights, supra note 7 , at 1194 .

26 See Butz v. Economou, 438 U.S. 478, 5 II-I2 (1978); supra note 20.

275 U.S. (I Cranch) I37, I63 (1803) (quoting 3 William Blackstone, Commentaries * iog). 
remedy for intra-litigation wrongs occurs within the lawsuit itself by appeal - rather than by a collateral damage action. ${ }^{28}$

\section{B. Separating the Two Tiers of Immunity}

In a lengthy and important footnote, the Nixon v. Fitzgerald majority properly rejected a wooden expressio unius reading of Article I, Section 6, arguing that "a specific textual basis has not been considered a prerequisite to the recognition of immunity."29 But the Court's desire to find a quick answer to Nixon's problem blinded it to the architecture of Section 6. To see this, we must carefully pull apart the two types of immunity mentioned in Article I. One type is "Immunity From Arrest": legislators' temporary immunity from litigating even private lawsuits while "at the Session" of Congress as public officers. The other type is "Immunity For Speech or Debate": permanent immunity from liability in lawsuits that arise out of the performance of public duties of democratic deliberation. This latter form is what all nine Justices in Nixon conceptualized as "immunity." 30

I. Permanent Immunity. - The Court's application of permanent immunity in Nixon was hard to justify by analogy to the Speech or Debate Clause or by other basic structural principles of constitutional law. Richard Nixon did not speak out against Ernest Fitzgerald in public debate; Nixon fired Fitzgerald from a civil service position. Worse still, Fitzgerald alleged that Nixon fired him because of Fitzgerald's speech activities - whistleblowing testimony before the Congress. A broad commitment to the constitutional ideals of democratic self-government and citizen speech argued against Nixon's immunity, not for it. According to Fitzgerald's complaint, Richard Nixon violated the Constitution itself (the First Amendment no less), ${ }^{31}$ and yet the Court shielded Nixon with permanent immunity.

28 See Akhil Reed Amar, Fourth Amendment First Principles, I07 HARv. L. Rev. 757, 781 (1994) [hereinafter Fourth Amendment].

${ }^{29} 457$ U.S. 731, 750 n.31 (1982); see also United States v. Nixon, 418 U.S. 683, 705 n.16 (1974) ("Nixon tapes case") (rejecting explicitly an expressio unius reading of the Speech or Debate Clause and embracing the notion of implicit presidential privileges).

30 The opinions in the case are rife with references to the Speech or Debate Clause as a benchmark for assessing presidential immunity. See, e.g., Nixon v. Fitzgerald, 457 U.S. 731 I, $75^{\circ}$ n.3I (1982); id. at 759 (Burger, C.J., concurring); id. at $77 \mathrm{I}$ (White, J., dissenting). Justice White's dissent alone refers no less than six times to the Speech or Debate Clause. See id. at 765,769 , 77 I \& n.6, 777 n.22, 781 .

31 See Nixon, 457 U.S. at 740 . Note that our commonplace description of Nixon as a "First Amendment case" is based on the idea, taken for granted by virtually the entire legal community, that mere presidential action can violate the First Amendment notwithstanding the Amendment's reference to "Congress" and the expressio unius maxim. See supra Part I.A. In New York Times Co. v. United States, 403 U.S. 713 (I97I), a case involving unilateral presidential attempts to suppress publication of the so-called Pentagon Papers, no Justice argued that the absence of a congressional law meant that the First Amendment was inapplicable or irrelevant. 
The five-Justice majority in Nixon prominently relied on an important quotation from Justice Joseph Story's classic Commentaries on the Constitution and, less prominently, on the words of Thomas Jefferson and John Adams. ${ }^{32}$ But as we shall show, all of these sources were badly misread in Nixon..$^{33}$ The Nixon five also dismissed, too quickly, the concern that permanent immunity for Richard Nixon would leave Ernest Fitzgerald with a constitutional right without an adequate legal remedy. ${ }^{34}$ The Court pointed to longstanding judicial immunities, ${ }^{35}$ but as we suggested earlier, these immunities do not necessarily violate Marbury's bedrock teaching that every right must have a remedy. ${ }^{36}$

The Nixon five also trotted out various newfangled executive immunities to blunt the message of Marbury. ${ }^{37}$ But the Framers would have been shocked by the notion that, as a general matter, executive officials could violate the Constitution and yet be held permanently immune. The modern judicial proliferation of various qualified immunities for constitutional torts is a twentieth century betrayal of founding principles. These immunities should be sources of concern things to be minimized or, ideally, eliminated - rather than springboards for further violations of Marbury. The Nixon five's complacent apologetics here are embarrassing, at least to those who value the Framers' first principles. ${ }^{38}$

The only real argument left in Nixon was the claim that Ernest Fitzgerald had alternative remedies - remedies against the government itself rather than Nixon personally - that would fully vindicate his constitutional rights. ${ }^{39}$ If true, this would indeed satisfy Marbury, for the government may limit a plaintiff's choice of constitutional remedies as long as those remaining suitably vindicate the right at stake..$^{40}$ Marbury and the rule of law demanded constitutional justice for Fitzgerald $^{41}$ but not necessarily a pound of flesh from Nixon himself. The

32 See Nixon, 457 U.S. at $749,75 \mathrm{I}$ n.31.

33 See infra Part I.C.

34 See Nixon, 457 U.S. at 754 n.37, 758 n.4I.

35 See id. at $745-46$.

36 The idea here may be that, in order to bring the outside world under the rule of law, courts must exist and function; but in order to function, they must adopt special rules for in-court wrongs. One can also argue that a judicial action, even if egregiously wrong, is not "unconstitutional" so long as the erring judge has "jurisdiction." Jurisdiction is the right to decide - either way - and thus, in effect, the right to be "wrong."

37 See, e.g., Nixon, 457 U.S. at 745-47 (relying on "good faith" immunity cases).

38 For a very different view of immunity and Marbury than Nixon's, see Akhil Reed Amar, Of Sovereignty and Federalism, 96 YALE L.J. 1425, 1484-92 (1987) [hereinafter Of Sovereignty].

39 See Nixon, 457 U.S. at $736-39$ \& n.17, 754 n.37.

40 See Henry M. Hart, Jr., The Power of Congress to Limit the Jurisdiction of Federal Courts: An Exercise in Dialectic, 66 HARV. L. REv. 1362, 1366-70 (1953).

41 Impeachment provided a remedy against Nixon but not one for Fitzgerald - not one that fully compensated him for the deprivation of his personal constitutional rights. The Nixon majority's emphasis on impeachment, see 457 U.S. at $757,758 \mathrm{n} .4 \mathrm{I}$, was thus unresponsive to the guiding principle of Marbury. Contrary to the Nixon five's intimations, see id. at $754 \mathrm{n} .37$, the 
government, after all, could have directly indemnified Nixon for any judgment that he owed to Fitzgerald, and a Fitzgerald suit against the government itself would simply accomplish this result more directly. But the Nixon dissenters denied the adequacy of alternative remedies, ${ }^{42}$ and the Nixon majority spent little time defending its claim of adequate alternatives.

2. Temporary Immunity. - The other half of immunity, temporary immunity akin to Article I immunity from arrest, went wholly unnoticed by Nixon's nine Justices. As Article I makes clear, members of Congress are privileged from arrest while Congress is in session. The Framers intended "Arrest" in this Clause to mean civil arrest, not criminal arrest. The Arrest Clause explicitly exempts cases of "Treason, Felony and Breach of the Peace"; and both the clear language of Blackstone's Commentaries and English debates well known to the Framers stressed that this exempting phrase was a term of art encompassing all crimes. ${ }^{43}$

Marbury Court did give William Marbury a remedy rather akin to the commission he sought: the Court's opinion was itself, like a commission, an official government document that declared that Marbury was indeed a justice of the peace. In addition, the Court's opinion on the merits supporting Marbury could serve as guidance to any other court in which Marbury might choose to refile. Marbury in word and deed upheld a plaintiff's right to a judicial remedy; Nixon did not.

42 See id. at 797 (White, J., dissenting).

43 For an excellent discussion, see Williamson v. United States, 207 U.S. 425, 436-46 (Igo8). See also Gravel v. United States, 408 U.S. 606, 6I4 (I972) ("History reveals, and prior cases so hold, that this part of the Clause exempts Members from arrest in civil cases only."); United States v. Brewster, 408 U.S. 50I, 521 (1972) (arguing that treason, felony, and breach of the peace encompass all crimes); Long v. Ansell, 293 U.S. 76, 83 (1934) ("When the Constitution was adopted, arrests in civil suits were still common in America. It is only to such arrests that the provision applies." (footnote omitted)); 2 JOSEPH STORY, COMMENTARIES ON THE CONSTITUTION OF THE UNITED STATES $\$ 862$ (Boston, Hilliard, Gary \& Co. 1833) ("Now, as all crimes are offences against the peace, the phrase 'breach of the peace' would seem to extend to all indictable offenses ....").

Williamson relied in part on Blackstone:

It is to be observed that there is no precedent of any such writ of privilege, but only in civil suits .... And therefore the claim of privilege hath been usually guarded with an exception as to the case of indictable crimes; or, as it has been frequently expressed, of treason, felony and breach (or surety) of the peace. Whereby it seems to have been understood that no privilege was allowable to the members, their families or servants, in any crime whatsoever, for all crimes are treated by the law as being contra pacem domini regis.

Williamson, 207 U.S. at 439-40 (quoting I William Blackstone, Commentaries * 66 ). Despite Williamson's correct use of Blackstone, the Court elsewhere quoted language that first appeared in the 1773 fifth edition and was refined in the 1783 ninth edition, not in 1765 , as the Court claimed. Compare i William Blackstone, Commentaries on the Laws of England I65 (4th ed. I770) (Oxford, Clarendon Press 1765) (omitting key sentence) with I WiLliam Blackstone, Commentaries on the Laws of ENGland i65 (5th ed. 1773) (Oxford, Clarendon Press i 765) (adding key sentence) and i William Blackstone, Commentaries on the Laws of ENGland 165 (8th ed. I778) (Oxford, Clarendon Press 1765) (reprinting key sentence from fifth edition) and I William Blackstone, Commentaries on the Constitution of ENGLAND I65 (Richard Burn ed., 9th ed. I783) (Oxford, Clarendon Press 1765) (revising key sentence). 
The real question is whether civil arrest should be understood strictly and formally, or more functionally. Technical civil arrest commencing a lawsuit by seizing the civil defendant's person - is all but dead today, and so the Arrest Clause, when strictly construed, shrinks to a virtual nullity. But "Arrest" may also be understood more functionally as extending to various civil cases that interfere with that arrest - a person's performance of her duties in public office. ${ }^{44}$

44 Despite a narrow interpretation of this Clause in Justice Brandeis's short opinion in Long, 293 U.S. at $82-83$, a broader reading may square better with the understanding of the Clause at the Founding. In Geyer's Lessee v. Irwin, 4 U.S. (4 Dall.) 107, 197 (Pa. 1790), the Pennsylvania Supreme Court decided that a member of the Philadelphia General Assembly was "undoubtedly, privileged from arrest, summons, citation, or other civil process, during his attendance on the public business confided to him. . . . [H] is suits cannot be forced to a trial and decision, while the session of the legislature continues." Id. at ro7. In Bolton v. Martin, I U.S. (I Dall.) 296 (C.P. Phila. 1788), a delegate to the Philadelphia Constitutional Convention was served with a summons. He pled privilege, and the plaintiff's counsel responded by arguing that "the protection of a member of the House of Parliament, extended only to the case of arrests, or personal restraint, and not to the service of a Summons." Id. at 297 (citations omitted). The court disagreed in language that is clear support for temporary immunity:

[M]embers of Parliament were privileged from arrests, and from being served with any process out of the Courts of law ... during the sitting of Parliament . . . . The act further directs, that where any plaintiff shall by reason of privilege of Parliament be stayed from prosecuting any suit commenced, such plaintiff shall not be barred by the statute of limitations, or nonsuited, dismissed, or his suit discontinued for want of prosecution, but shall, upon the rising of Parliament, be at liberty to proceed.

....

We cannot but consider our Members of Assembly, as they have always considered themselves, intitled by law to the same privileges. They ought not to be diverted from the public business by law suits, brought against them during the sitting of the House; which, though not attended with the arrest of their persons, might yet oblige them to attend to those law suits. . . .

The Defendant, therefore, must be discharged from the action.

Id. at 303-05. Functional reasons led this court to stretch immunity along another axis - by protecting members of the Philadelphia Convention, who had no explicit textual provision to protect them: "The members of Convention, elected by the people, and assembled for a great national purpose, ought to be considered in reason, and from the nature, as well as dignity, of their office, as invested with the same or equal immunities with the members of General Assembly . . ." Id. at 303 . Fifty years later, another court agreed with the idea of temporary immunity from all civil process:

For, antecedent to this statute, [sitting] members of parliament were not only privileged from arrest, but also from being served with any process out of the courts of law .... [The statute provides] what may be a just construction of the rule in this country - "that the plaintiff is not to be barred by the statute of limitations" in the time consumed by the privilege, but is at liberty to proceed de novo after the cessation of privilege, which, being a public right, enjoyed for the benefit of the public, only so far interferes with private right as to secure the public good, on the termination of which the private right re-commences, unimpaired by the time of privilege, the statute of limitations ceasing to run when privilege commenced. ...

... [The privilege] is consistent with, nay, necessary to the universal equality established in a republic. It is inseparably connected with the fundamental maxim in all free governments, that where the public exigency renders it necessary, for common preservation, private right shall yield to public good.

The privilege ... protects them, while in attendance upon their public duties from arrest, summons, or any other civil process. 
This functional immunity avoids undemocratic results: functional civil arrests of members of Congress while it is in session might skew votes in Congress and penalize innocent third parties, namely, the American people. As Joseph Story put the point in his Commentaries, explicitly building on Thomas Jefferson's famous Congressional Manual:

When a representative is withdrawn from his seat by a summons, the people, whom he represents, lose their voice in debate and vote ... . When a senator is withdrawn by summons, his state loses half its voice in debate and vote .... The enormous disparity of the evil admits of no comparison. ${ }^{45}$

But Article I prohibits civil arrests only while Congress is in session; it implicitly permits the arrests when Congress is not in session. (And here we see a less wooden and more proper application of the expressio unius maxim.) Arrest Clause immunity is thus temporary immu-

Lyell v. Goodwin, I5 F. Cas. I 126, I I27-30 (C.C.D. Mich. I845) (No. 8,616). Lyell explicitly supported the temporary immunity idea, noting that the plaintiff could bring suit when the defendant had ceased his public duties:

For the time being, while engaged in the public service, he is divested of self and of private concernment, and, as it were, dedicated in time and mind to the public service. Nor need there be private injury as a necessary consequence. There may be a time, when the privilege of these functionaries ceases, - when the special duty, that sets them apart to the public service has been performed, and their return to private life is clear and unquestioned, when the public interest no longer demands their protection, and the private right to their attention can commence, and they be held answerable as any other citizen.

Id. at I I $3 \mathrm{I}$.

The Wisconsin Supreme Court put a similar gloss on Article I, § 6:

In order to render this provision available to the extent of its necessity, it will not do to construe the words privilege from arrest in a confined or literal sense. A liberal construction must be given to these words upon principle and reason. It is just as necessary for the protection of the rights of the people that their representative should be relieved from absenting himself from his public duties during the session of congress, for the purpose of defending his private suits in court, as to be exempt from imprisonment on execution. If the people elect an indebted person to represent them, this construction of the constitution must also be made to protect his rights and interests, although it may operate to the prejudice of his creditors; but the claims of the people upon his personal attendance are paramount to those of individuals, and they must submit.

Doty v. Strong, I Pin. 84, $87-88$ (Wis. I 840). Doty, in the spirit of Bolton, stretched Article I's immunity to cover delegates to Congress from territories. See id. at 88; see also Juneau Bank v. McSpedan, I4 F. Cas. 5I, 52 (C.C.D. Wis. 1860) (No. 7,582) ("In England, the privilege from arrest has always been construed to include the service of a summons. So in this country from a very early period."); Nones v. Edsall, 18 F. Cas. 296, 297 (C.C.D.N.J. I848) (No. I0,290) (Grier, Cir. J.) ("Members of congress are privileged from arrest both on judicial and mesne process, and from the service of a summons or other civil process while in attendance on their public duties."); Anderson v. Rountree, I Pin. I I5, II7, I24 (Wis. I84I) (following Doty).

Later courts, in decisions such as Long $v$. Ansell, rejected this early broad reading of arrest. Long properly noted that the court in Bolton had quoted language from an early edition of Blackstone that had been changed in post-I 773 editions. See Long, 293 U.S. at 82 n.3. But Long simply sidestepped the broader functional vision underlying all the early cases rooted in the democratic public interest served by the privilege.

452 STORY, supra note $43, \S 857$ (footnote omitted). Note that Story explicitly extended the functional logic of the Arrest Clause beyond arrests to various "summons[es]," see id., as did Jefferson's Manual. See Thomas Jefferson, A Manual of Parliamentary Practice i5-22 (New York, Clark \& Maynard I873). 
nity - stopping the clock on a lawsuit until litigation can occur without disruption of the defendant's public duties. ${ }^{46}$

Though a strict expressio unius reading might limit the Arrest Clause to "Senators and Representatives," structural considerations tug the other way. Consider, for example, the Vice President. Surely he is not a "Senator or Representative," strictly speaking, ${ }^{47}$ and yet under the Constitution, he is empowered to preside over the Senate and cast a tie-breaking vote. ${ }^{48}$ If he were subject to civil arrest while Congress was in session, he could be wrenched away from these weighty constitutional duties of democratic deliberation by a single private plaintiff, in clear violation of the spirit and logic - but not the letter - of the Arrest Clause.

The structural constitutional logic undergirding temporary immunity applies with even greater force to the President. Unlike federal lawmakers and judges, the President is at "Session" twenty-four hours a day, every day. Constitutionally speaking, the President never sleeps. The President must be ready, at a moment's notice, to do whatever it takes to preserve, protect, and defend the Constitution and the American people: prosecute wars, command armed forces (and nuclear weapons), protect Americans abroad, negotiate with heads of state, and take care that all the laws are faithfully executed. We should hesitate before arming each citizen with a kind of legal assault weapon enabling him or her to commandeer the President's time, drag him from the White House, and haul him before any judge in America.

What's more, the President is the only person for whom the entire nation - We the People of the United States - votes. There are over 500 federal lawmakers - the House and Senate can function if one member is absent, as the quorum rules of Article I, Section 5 make clear ${ }^{49}$ - but there is only one President, in whom all executive power is vested by Article II. ${ }^{50}$ Thus, the democratic skew that can result if civil suits impede - arrest - the President is far more dra-

46 For many explicit expressions of this point, see note 44 above.

47 See Richard D. Friedman, Some Modest Proposals on the Vice-Presidency, 86 Mich. L.

REV. I 703, I 720-2 I (I988).

48 See U.S. Const. art. I, $\S 3$, cl. 4.

49 See id. art. I, $\$ 5$, cl. I ("[A] Majority of each [House] shall constitute a Quorum to do Business").

50 See id. art. II, $\S \mathrm{I}$, cl. I ("The executive Power shall be vested in a President") (emphasis added). On the importance of the vesting mandate and the unitary executive it creates, see Two Tiers, cited above in note 25, at 23I-32 \& n.92, 25I-52 \& n.15 I (I985); and Steven G. Calabresi \& Kevin H. Rhodes, The Structural Constitution: Unitary Executive, Plural Judiciary, I05 HaRv. L. REV. I I53, I I75-79 (I992). See also Memorandum For the United States Concerning the Vice President's Claim of Constitutional Immunity, In Re Proceedings of the Grand Jury Impaneled December 5, 1972, at 18 (Civ. No. 73-965) (Brief filed by Solicitor General Robert Bork in Maryland District Court) ("[T]he President is the only officer whose temporary disability while in office incapacitates an entire branch of government."). 
matic than for a typical Representative or Senator. To be sure, the Vice President always remains at hand, ready to step in for the President in emergency situations, but the elaborate provisions of the Twenty-Fifth Amendment and past practice indicate that these emergencies should be the exception, not the rule. ${ }^{51}$ Yet they could well become the rule if a handful of citizens - acting independently or in concert $^{52}$ - could functionally arrest the President in his performance of the people's business and trigger his temporary inability "to discharge the Powers and Duties of . . . Office" under Article II and the Twenty-Fifth Amendment.

This approach does not mean that the President is above the law. It simply means that, in cases seeking compensation for past wrongs, a President should be able to request temporary immunity to avoid interference with his duties. ${ }^{53}$ Whereas Nixon eliminated all remedies against the President, at least for constitutional torts committed qua President, arrest immunity would only "toll" - stop the clock on - a lawsuit and would preserve the plaintiff's ultimate remedy and vindicate the ideal of Marbury. ${ }^{54}$ Because of the Twenty-Second Amend-

51 Because of the common practice of "balancing" a ticket with presidential and vice-presidential candidates from different "wings" of a party, a shift of presidential power from President to Vice President can cause a serious democratic skew. For historical examples and discussion, see Akhil Reed Amar \& Vik Amar, President Quayle?, 78 VA. L. REV. 913, 938-39 \& n.76 (1992). For a general discussion of succession issues and the Twenty-Fifth Amendment, see Akhil Reed Amar, Presidents, Vice Presidents, and Death: Closing the Constitution's Succession Gap, 47 ARK. L. REV. (forthcoming 1994).

52 The issue raised by the Jones suit thus radiates far beyond Jones herself. The issue is one of precedents and slippery slopes: we must ask not merely what would happen if Jones's suit goes forth but what would happen if suits like hers can go forth and multiply.

53 This immunity is of course waivable. Surely the President in whatever spare time he has should be allowed to litigate civil damage actions - or to watch basketball for that matter - but he should not be legally obliged to do either. As a practical matter, politics may sometimes create strong pressure to litigate now - or, again, to watch a basketball game - but political pressure should not be confused with legal obligation. In a civil damage action in the early i 9605 , thenPresident John Kennedy asserted litigation immunity under a statute. When that failed, he settled the case instead of asserting presidential immunity - a choice wholly consistent with our analysis. See Memorandum in Support of President Clinton's Motion to Dismiss on Grounds of Presidential Immunity at 29 n.r9, Jones v. Clinton (E.D. Ark. July 2 I, I 994) (No. LR-C-94-290).

54 Beyond Marbury's vision that the ideal of "a government of laws, and not of men" entails that "the laws furnish [a] remedy for the violation of a vested legal right[,]" 5 U.S. (I Cranch) I35, I63 (I803), there is perhaps another basic element of the rule of law: the idea of no "special treatment" based on status. But temporary immunity for a sitting President comports with this norm too: Bill Clinton can toll a suit not because of who he is, but because of what he does what he is now doing for the American people in serving them as their elected President. (Richard Nixon, by contrast, sought a lifetime pass from legal accountability even when he was serving no one but himself.) Presidential arrest immunity simply applies a general functional principle to the unique circumstances of a sitting President preoccupied with weighty affairs of state. Temporary tolling occurs in many other contexts in which similar hardship would be created by immediate litigation - for example, cases involving military officers on duty, persons temporarily beyond the jurisdiction, and persons with temporary illnesses. See, e.g., Soldiers' and Sailors' Civil Relief Act of I940, 50 U.S.C. app. §§ 50I-525 (1988 \& Supp. I994). 
ment, the Constitution itself assures that plaintiffs will not have to wait more than eight years. ${ }^{55}$

But eight years is a long time - much longer than any "Session" of Congress under Article I, Section 6 - and so perhaps the Section 6 analogy breaks down at precisely that point. On the other hand, eight years is a lot shorter than eternity, which is how long the Nixon Court said Ernest Fitzgerald had to wait. On this point, at least, it may be politically awkward for the Court to distinguish Nixon: aren't Democratic Presidents entitled to the same solicitude as Republican Presidents? (And on the facts of the Jones case, one may well ask if Paula Jones can equitably complain about delay after she waited three years to file her complaint. $)^{56}$

If sensible structural inferences lead us to think that a President, under the logic of Article II, merits an immunity akin to Section 6 "Arrest" immunity, it becomes important to refine further the functional concept of civil arrest. Our legal order has long distinguished between damage suits for past, discrete wrongs, and injunctive suits to end ongoing harm. In effect, we should distinguish between civil damage arrests and ongoing harm injunctions. In arrest scenarios, plaintiffs may be obliged to wait, but interest payments presumably can make up for lost time. Civil actions arising out of ongoing harms continuing possession of a steel mill in Youngstown, ${ }^{57}$ or a hypothetical divorce or child custody suit involving a sitting President - are quite different. $^{58}$ Putting the point more textually, perhaps one could say that an ongoing harm is functionally one kind of "Breach of the Peace" and thus lies outside the proper scope of arrest immunity. ${ }^{59}$

\section{Nixon Revisited}

Not only does temporary immunity from "civil arrest" make good sense from the perspective of constitutional structure and policy, but it also makes the most sense of the historical evidence offered up by the

55 U.S. Const. amend. XXII, $\S_{\text {I }}$ ("No person shall be elected to the office of the President more than twice ...."). In rare cases, the Amendment would allow a person to serve as President for ten years. See id.

56 See infra Part II.

57 See Youngstown Sheet \& Tube Co. v. Sawyer, 343 U.S. 579, 585 (1952).

58 The circle of potential plaintiffs in a divorce or child custody case is, of course, much smaller than the circle of potential plaintiffs who might seek damages for any past act, public or private. Injunctive suits arising out of a sitting President's private business concerns are also imaginable - consider, for example, a tort injunction to abate an alleged nuisance on land owned by the President. But if a sitting President deemed such nuisance suits a nuisance, he might well be able to place his business affairs in a blind trust and thereby free himself from distraction. This is not a realistic option for damage suits that arise out of past discrete acts rather than alleged ongoing harms.

59 See supra p. 710 (discussing the breach of the peace language of the Arrest Clause). Obviously, mere refusal to pay damages for a past discrete harm during the tolling of a suit should not be seen as an "ongoing harm." 
Nixon majority. The best evidence that the Nixon five had for their position, Justice White's dissent conceded, was from Justice Story. But now that we have tipped our hand and identified two types of immunity, listen to Story's words with fresh ears:

There are ... incidental powers, belonging to the executive department, which are necessarily implied from the nature of the functions, which are confided to it. Among these, must necessarily be included the power to perform them, without any obstruction or impediment whatsoever. The president cannot, therefore, be liable to arrest, imprisonment, or detention, while he is in the discharge of the duties of his office; and for this purpose his person must be deemed, in civil cases at least, to possess an official inviolability. ${ }^{60}$

Let us note carefully Story's moves. First, Story believes that Section 6 does not exclude immunities for coordinate federal branches. In particular there are "incidental" presidential powers, not textually spelled out but "necessarily implied" by the spare words of Article II. Next, Story hints that these immunities should be understood functionally, not formally - they are deducible from the nature of presidential "functions." Third, Story articulates presidential immunity as an immunity from "arrest" - obviously conjuring up an analogy to the Arrest Clause of Article I, rather than the Speech or Debate Clause.61 Fourth, this immunity is explicitly temporary, once again in keeping with arrest immunity rather than speech or debate immunity. It is immunity "while he is in the discharge of the duties of his office" while he is in "Session," in the analogous language of Section 6. Fifth, it is immunity even for certain lawsuits based on a President's private conduct - immunity for his "person." Once again, this tracks arrest immunity rather than speech or debate immunity. Finally, Story carefully limits this immunity to "civil cases" - just as the Arrest Clause (but not the Speech or Debate Clause) is limited to civil cases.

This quote from Story could be challenged, or narrowly construed, were we writing on a clean slate. Perhaps Story is referring only to technical civil arrests, rather than to broader litigation impediments. In any event, Story is not speaking in his judicial capacity, but only as a commentator on the Constitution (though perhaps its most distinguished commentator), and is writing almost fifty years after the document's ratification.

Today, however, we do not write on a clean slate. We write in the wake of Nixon. A very broad reading of Story is inscribed in the United States Reports - it is the rock on which Nixon is built. If

603 STORY, supra note $43, \S 1563$.

61 In light of the rather precise parallels of language and logic between Justice Story's discussion of the Arrest Clause in $\$ \$ 856-62$ and his discussion here in $\S 1563$ of implicit presidential immunities, it is hard to see the parallels as wholly unconscious or coincidental. The same structural vision informs both passages. See 2 id. $\$ \$ 856-62 ; 3$ id. $\$$ I563 . 
Story was enough to win for Nixon, why not for Clinton? (Nixon was a Republican, and Clinton is a Democrat, but of course this should make no difference. ${ }^{62}$ Indeed, as should be clear by now, a careful reading of Story does not support the result in Nixon, ${ }^{63}$ contrary to Justice White's glib concession in dissent. ${ }^{64}$ But a close reading of Story does support Clinton and our Arrest Clause methodology today.

The Nixon majority had a couple of other high cards up its sleeve, a pair of quotations from Thomas Jefferson and John Adams featured in a long and important footnote that addressed the Article I, Section 6 expressio unius argument. Here are Jefferson's words:

62 Nixon recognized presidential immunity in the absence of an express congressional statute to the contrary. See Nixon v. Fitzgerald, 457 U.S. 73 I, 748 \& n.27 (I982). So too, we today propose only a Category Two arrest immunity. See supra note $2 \mathrm{I}$. Like the Nixon Court, we do not reach the question of the precise scope of congressional power to restrict this immunity.

63 The Nixon Court should have been aware of the real argument in the Story quote. Fitzgerald's brief declared:

Mr. Nixon's countervailing citation from the 1830 's, like his other authorities, concerns the amenability of an incumbent President to process in a civil suit. The "official inviolability" that Justice Story referred to in his Commentaries was, by its own terms, limited to acts arrest, imprisonment, and detention - that would obstruct or impede the President "while he is in the discharge of his duties of his office." Neither Story nor any other source cited by Mr. Nixon supports the proposition that a former President, when out of office, is immune from civil liability for his acts while President.

The distinction between an incumbent and a former President is important. It was recognized at the time the Constitution was ratified. And it was strenuously argued to this Court in 1867. Attorney General Stanbery then asserted on behalf of President Andrew Johnson that the President "is above the process of any court to bring him to account as President." But Stanbery acknowledged that this immunity ended with the President's removal from office. When "he no longer stands as the representative of the government," Stanbery said,

then for any wrong he has done to any individual, for any murder or any crime of any sort which he has committed as President, then and not till then can he be subjected to the jurisdiction of the courts. Then it is the individual they deal with, not the representative of the people.

Brief for Respondent at I9, Nixon (Nos. 79-1738 and 80-945) (footnotes omitted). Fitzgerald's brief acknowledged that a suit against an incumbent President would be altogether different:

Nixon's arguments obscure a crucial fact about the lawsuit at issue in this case. It was not brought against an incumbent President. Mr. Nixon was named as a defendant in July, 1978, nearly four years after he resigned as President. Whatever drain on his time and resources the suit has caused occurred long after he left office; it had no effect on his performance of public duties.

Id. at 26 .

Indeed, Fitzgerald's brief conceded tolling: "The burdens of litigation are not as onerous for the President or a former President as petitioner claims. With respect to the incumbent, the district court can stay all proceedings until he leaves office." Id. at 28; see also Memorandum of Justice Powell, 6th Draft at 22 n.27, Kissinger v. Halperin, 452 U.S. 7 I3 (198I) (No. 79-880), April 6, I98I (unpublished draft opinion in pre-Fitzgerald case from Thurgood Marshall Papers, Library of Congress, Box 268, folder 2) (acknowledging in a footnote discussing Story, Ellsworth, Adams, and Jefferson that "[t]he statements quoted here concerning a President's amenability to process apply only to sitting Presidents").

64 See Nixon, 457 U.S. at 776 (White, J., dissenting) (conceding that the Story passage "clearly supports [Nixon's] position but it is of such a late date that it contributes little to understanding the original intent"). 
But would the executive be independent of the judiciary, if he were subject to the commands of the latter, \& to imprisonment for disobedience; if the several courts could bandy him from pillar to post, keep him constantly trudging from north to south \& east to west, and withdraw him entirely from his constitutional duties?65

And here are the thoughts attributed to Adams and Senator Oliver Ellsworth: "[T]he President, personally, was not the subject to any process whatever .... For [that] would ... put it in the power of a common justice to exercise any authority over him and stop the whole machine of Government." 66

As with the Story quote, these passages support Clinton far more than Nixon. Jefferson is clearly concerned about litigation that would "withdraw" a President from his current "constitutional duties" - a concern inapplicable to Nixon in 1982 but very much relevant to Clinton today. As Jefferson put the point three days earlier in words that obviously apply only to sitting Presidents: "To comply with such calls would leave the nation without an executive branch, whose agency, nevertheless, is understood to be so constantly necessary, that it is the sole branch which the constitution requires to be always in function."67 Note also how Jefferson's later reference to "imprisonment for disobedience" conjures up arrest, not speech or debate.

As Adams and Ellsworth's last six words suggest, they too are referring to a sitting President, not a former one: only suits against a sitting President would "stop the whole machine of Government." Significantly, Adams and Ellsworth's language goes beyond technical civil arrest and defines temporary immunity functionally to subsume "any process whatever." Their sweeping quote thus encompasses both civil and criminal prosecutions, yet surely they are not claiming, in light of the Article I, Section 3 Impeachment Clause, ${ }^{68}$ that a former President may not be criminally punished for offenses in office. Indeed, in language that all of the Nixon opinions overlooked, Adams and Ellsworth explicitly concede as much moments later and thus make clear that

65 Nixon, 457 U.S. at 750 n.3I (quoting letter from Thomas Jefferson to George Hay (June 20, i807), in ro The Works of Thomas Jefferson 404 (Paul L. Ford ed., 1905)).

66 Id. (quoting William Maclay, The Journal of William Maclay, United States Senator from Pennsylvania, 1789-1791 i67 (Edgar S. Maclay ed., i89o)).

67 Letter from Thomas Jefferson to George Hay (June I7, 1807), in II THE WRITINGS OF Thomas JefFerson 232 (Andrew A. Lipscomb ed., r905).

68 U.S. ConsT. art. I, $\S 3$, cl. 6 ("[B]ut the Party convicted [in an impeachment court] shall nevertheless be liable and subject to Indictment, Trial, Judgment and Punishment, according to Law."). 
they are not talking about suits against ex-Presidents. ${ }^{69}$ So here too, the Court badly misread the historical evidence. ${ }^{70}$

The stunning part of Nixon is not only the majority's hands-off attitude towards an ex-President, but also the fact that none of the nine Justices seemed to understand what Story, Jefferson, and Adams were really saying. ${ }^{71}$ We can now understand why Eastland and others might question the Court's view that "[t]he best historical evidence clearly supports the Presidential immunity we [the Court] have upheld."72 But the fact that the evidence fails to support Nixon

69 In response to Maclay's statement that, "altho, President he was not above the laws," Ellsworth and Adams "declared You could only impeach him. [sic] and no other process Whatever lay against him." The Diary of William Maclay and Other Notes on Senate Debates i68 (Kenneth R. Bowling \& Helen E. Vett eds., I972). Maclay then "put the Case suppose the President commits Murder in Streets. . . . But You can only remove him from Office on impeachment." Id. Listen carefully to Adams and Ellsworth's response: "Why When he is no longer President, You can indict him." Id. (emphasis added).

As with the Story quote, the Nixon Court ignored Fitzgerald's admonition about the applicability of the quote from Adams and Ellsworth:

The statements made in the course of framing and ratifying the Constitution do not support Nixon's position. Nor do the observations of John Adams and Oliver Ellsworth ....

These observations . . a addressed a question that is not before the Court in this case: namely, whether an incumbent President is amenable to process in a civil suit.

Brief for Respondent at I8, Nixon (Nos. 79-1738 and 80-945).

70 See Nixon, 457 U.S. at $75 \mathrm{I} \mathrm{n.31.} \mathrm{The} \mathrm{Court} \mathrm{introduced} \mathrm{the} \mathrm{Adams/Ellsworth} \mathrm{quote} \mathrm{with}$ the - embarrassingly untrue - claim that Adams had served as a delegate at the Philadelphia Convention. See Max Farrand, The Framing of the Constitution of the United States I4-4 I ( $19 \mathrm{I}_{3}$ ) (discussing the delegates); id. at 39 (noting that John Adams was in London).

71 In essence, all three were arguing for litigation immunity rather than substantive immunity for sitting Presidents - immunity from claims made while President rather than for conduct occurring while President. (As Ian Ayres has pointed out to us, the distinction is akin to the claims-made/occurrence distinction in modern insurance policies.) Litigation immunity protects a worthy plaintiff (because it merely postpones suit), whereas substantive immunity does not (because it bars suit). Litigation immunity deters conduct while in office - but conduct that is by hypothesis unconstitutional and should be deterred by the prospect of a later damage suit. Substantive immunity does not chill this conduct; instead it immunizes even clearly unconstitutional actions - and that is why the Founders rejected it. See Of Sovereignty, supra note 38 , at I 484-92.

If we are concerned that mere litigation immunity will lead to a flood of frivolous lawsuits (or even nonfrivolous but ultimately unworthy ones) against ex-Presidents, we should not recognize a substantive immunity that bars worthy and unworthy claims alike. Instead we should provide for fee-shifting, which discourages plaintiffs with weak claims and yet fully preserves remedies for plaintiffs with winning claims. See id. at I514 n.346. If Congress fears that the threat of liability for good faith mistakes will overdeter and paralyze Presidents (or other officials, for that matter), Congress need only provide for indemnification for good faith mistakes, for which government is in effect the better risk bearer than its employees in a Coasean world. See id. at 1515; Fourth Amendment, supra note 28 , at 812 .

In light of this anaiysis the real timing difference between Nixon and Clinton is not Eastland's and Meese's occurrence-based difference that favors Nixon, see supra pp. 701-02, but a claims-made difference that favors Clinton.

72 Nixon, 457 U.S. at 752 n.3I. It is also worth noting that Justice White's dissent argued that United States v. Burr, 25 F. Cas. 30 (C.C.D. Va. 1807) (No. 14,692), demonstrates that the President is "subject to judicial process." Nixon, 457 U.S. at $78 \mathrm{I}$ (White, J. dissenting). The 
doesn't mean that the same goes for Clinton. On the contrary, even if Nixon is a twisted stretch of history and text, the historical evidence does provide sturdy support for temporary immunity from arrest. ${ }^{73}$

majority did not disagree with this conclusion. See Nixon, 457 U.S. at 753-54. These Nixon opinions overlooked the fact that Burr was not an unavoidable intrusion on the President, for the President had the power to dismiss the prosecution at any time if he considered Burr's request for exculpatory material too onerous. Put another way, by continuing to hold Burr in detention, Jefferson voluntarily incurred certain duties, the disregard of which would be a kind of ongoing breach of the peace as long as Jefferson insisted on holding Burr in jail for trial. Any subpoena against Jefferson would have been a true negative injunction - provide evidence in your possession or let Burr go - that could have been enforced, Marbury-like, without an awkward coercive order against Jefferson. Chief Justice Marshall could simply quash the indictment and let Burr free, much as he simply refused to take jurisdiction in Marbury itself.

Nor does the Nixon tapes case, United States v. Nixon, 4 I8 U.S. 683 (I974), preclude temporary immunity. As in Burr, the President could have avoided any court-ordered mandate merely by ending the ongoing prosecutions, via a Caspar Weinberger-like pardon or by formally rescinding via the Attorney General an executive regulation and dismissing both the special prosecutor and the underlying prosecutions, as the Nixon tapes Court explicitly allowed. See id. at 694-96. (Of course, these actions might have created a huge political backlash, but so might insisting on arrest immunity rather than waiving it; once again, we must distinguish between legal obligation and political pressure. See supra note 53.) The Nixon tapes case is also of course distinguishable from the Jones litigation because the former involved allegations of presidential criminal wrongdoing, Nixon, 418 U.S. at 687 , which would overcome any arrest immunity deducible by analogy to the $\S 6$ Arrest Clause, see supra p. 7 10. Thus, the Nixon tapes case is an awkward springboard for any assault on implicit presidential arrest immunity. See also supra note 29 (noting that the Nixon tapes case explicitly an rejects expressio unius reading of Article I, $\S 6$ and affirms implicit presidential immunity).

The Nixon tapes case does contain some loose language, but all this must now be read in light of the later decision in Nixon v. Fitzgerald. Frankly, some of the loose language simply cannot be taken at face value today. See, e.g., Nixon, 4 I8 U.S. at 694-96 \& n.8 (1974) (treating as having "the force of law" a regulation that gave a kind of legislative veto to certain key congressional officials - a regulation that, as a binding law, rather than a political promise, would plainly violate basic constitutional principles acknowledged a few pages later, id. at 704, and resoundingly affirmed a few years later in I.N.S. v. Chadha, 462 U.S. 919, 945-46 (I983)); Nixon, 4 I8 U.S. at 709-13 (glossing over key differences between case at hand, in which the prosecutor was seeking to pierce presidential privilege to find inculpatory evidence and Burr-like cases in which defendant with due process rights sought exculpatory evidence). In the end, the Nixon tapes Court acquiesced in an untidy opinion by Chief Justice Burger that, on the facts of the case, reached the obviously right result. Richard Nixon was the head of an ongoing conspiracy to obstruct justice and was using the Oval Office itself as the hub of that conspiracy; and the Court had evidence under seal that made all this clear. See Nixon, 4 I8 U.S. at $687 \&$ n.4, 689, 700. The Court's occasionally strained readings of the Constitution, case law, and regulations must be analyzed in light of what the Court delicately described as the "unique setting" and "unique facts of this case." Nixon, 418 U.S. at 691,697 ; see also id. at 700 (stressing material under seal as the basis for the Court's conclusion); id. at 687-88, 70I (relying subtly on Nixon's status as an unindicted co-conspirator); id. at $7 \mathrm{I} 2 \mathrm{n} .20$ (invoking by analogy a case in which the strong presumptive privilege of jury deliberation proceedings yielded in the face of credible claims of criminal misconduct).

73 To put the point slightly differently, we are suggesting that President Clinton's immunity should not turn on whether his alleged conduct towards Jones was an "official" duty or not (a holdover of viewing immunity through the prism of the Speech or Debate Clause), but rather should turn on whether the Jones suit and others like it, see supra note 52 , could functionally "Arrest" the President while at "Session." 
Despite what the pundits are saying, Clinton has a far stronger case than Nixon had.

\section{Possible Privileges}

The concept of a President's immunity from functional "Arrest" while in "Session" is a modest one - waivable, temporary, and perhaps subject to congressional modification. Yet from another perspective, arrest immunity is absolute and categorical - it does not balance or weigh the unique features of a given case. It does not distinguish between a case likely to arrest the President in litigation for two hours, and one likely to arrest him for two months. It does not focus on the equities of a particular plaintiff or her special need for speedy adjudication. It does not reflect the fact that some claims are more difficult than others to revive and to adjudicate after a long delay.

For some, the bright-line quality of arrest immunity - supported by a textual analogy to the bright-line rule of Article I, Section $6,{ }^{74}$ by the categorical language of Story, Jefferson, and Adams, ${ }^{75}$ and by the prospect that political pressure can be trusted to induce presidential waiver in appropriate cases - will count as a juridical virtue. For others, the medicine of absolute arrest immunity will taste too strong. For those in this second group - scholars, lawyers, and judges - we shall briefly provide a catalogue of weaker prescriptions: presidential privileges attentive to the structural arguments and historical evidence presented above but packaged in lower dosages and blended with other general legal principles.

\section{A. Equitable Tolling}

In some situations, arrest immunity may work a grave injustice against a worthy and diligent plaintiff. Imagine a pedestrian crushed by a transition team bus (with Clinton at the wheel) one week before the Clinton inauguration. Obviously there is no time to file suit, conduct discovery, litigate the case, and pursue an appeal before Inauguration Day. This plaintiff might have to pay huge out-of-pocket hospital bills and yet, under absolute arrest immunity, may be forced to wait eight years to be made whole.

A more flexible, "equitable" version of presidential immunity would distinguish between cases in which a plaintiff could have brought suit before Inauguration Day and cases in which a plaintiff could not. The structural logic here is the same one that drives arrest immunity: a suit against a sitting President in effect impleads innocent third parties - the American people - whose democratically chosen leader is obstructed in discharging his unique and awesome constitutional duties.

74 See supra p. 702.

75 See supra Part I.C. 
But the application in this situation is more flexible and equitable. ${ }^{76}$ Only those cases in which plaintiffs themselves choose to sue while the President is in session are automatically tolled. Other cases (like our hypothetical pedestrian's) could be selectively tolled, depending on factors such as the likely amount of intrusion on a President's time, the practical freezability of a case, and the extent of out-of-pocket losses that call for quick recoupment.

With this rule in place, plaintiffs who have claims against would-be Presidents would have strong incentives to bring suit well before Inauguration Day. ${ }^{77}$ Pre-inaugural suits are exactly what constitutional structure and history counsel. The constitutional evil to be avoided is distracting - arresting - litigation while the President is at session. Litigation after - or before - a President's term is just fine. A bonus of equitable tolling is that pre-presidential litigation may bring information to light for the American people, as well as the courts, before We the People make our momentous choice on Election Day.

Under a regime of equitable tolling, Paula Jones's case looks rather different from our hypothetical pedestrian's. Jones saw the metaphoric Inauguration Bus coming; she was not blindsided. She did not suddenly wake up one day and discover - mirabile dictu - that Bill Clinton had become President. Why then, did Jones not bring suit much earlier, when the American people would not have been involuntarily dragged into litigation as de facto third party defendants and when litigation would not have disrupted constitutional government? Unless she can answer this question persuasively, an equitable tolling approach would put her lawsuit on hold. ${ }^{78}$

\section{B. Equitable Dismissal}

An equally flexible but more emphatic approach would dismiss Jones's suit with prejudice, unless she can persuasively explain why she sat on her claims until after Inauguration. Like tolling, dismissal would of course create strong incentives for future plaintiffs like Jones to bring suit before presidential elections rather than after them. Like tolling, dismissal is more flexible and less categorical than arrest immunity: dismissal would be case-specific, and could, for example, distinguish between Jones's suit and our hypothetical pedestrian's.

The idea here is that litigation delay - temporary immunity or tolling - at times hurts defendants and not just plaintiffs. A Presi-

76 One reason for a more flexible application of presidential arrest immunity stems from the greater potential hardship on plaintiffs than in the Article I context, since presidential "sessions" run much longer than congressional ones. See supra pp. 714-15.

77 "Well before" allows the case to be tried before Inauguration. Aware of the significance of Inauguration, the parties and the judges would probably expedite judicial proceedings.

78 Jones's case does not appear to be one of a repressed memory; her complaint claims that she told others about the alleged encounter with then-Governor Clinton within days of its occurrence. See Jones v. Clinton, Complaint, Civ. No. LR-C-94-29o (E.D. Ark. May 6, 1994). 
dent's memory of the facts of any one case will no doubt fade over eight years, while she is preoccupied by many and weighty matters of state, whereas a single-minded plaintiff may be able to rehearse his story over the years. This concern can vividly arise in a case turning on facts more than on law, especially if testimonial credibility is a key issue. By strategically manipulating the timing of a lawsuit - delaying without good reason until after Inauguration - a plaintiff may place a President who deserves to win the suit in a cruel trilemma: drop vital affairs of state to litigate now and prevail (the "betray the people/waiver" option), or pay off unmeritorious claims (the "nuisance value/extortion floodgates" option), or wait until out of office and defend at a disadvantage (the "can't remember/look like a liar or a dope" option). To discourage precisely this kind of strategic manipulation, Anglo-American law has long recognized the general doctrine of laches. ${ }^{79}$

Laches is a defense that allows a case to be dismissed if the plaintiff cannot explain why he sat on his claims and if his delay substantially prejudices the defendant. ${ }^{80}$ For example, the Supreme Court held over a century ago that a plaintiff alleging fraud could not needlessly delay a suit until after the alleged defrauder's death and thereby prevail more easily against the alleged defrauder's successors in interest. $^{81}$ This logic could easily be blended with arguments from consti-

79 See Joseph Story, Commentaries ON Equity JuRisprudence $\$ 1520$ (4th ed. I846) (Boston, Hilliard, Gray \& Co. I836) ("Courts of Equity . . . sometimes act upon their own inherent doctrine of discouraging, for the peace of society, antiquated demands by refusing to interfere, where there has been gross laches in prosecuting rights .... ").

80 The doctrine is used to "aid[ ] the vigilant and not those who slumber on their rights." NAACP v. NAACP Legal Defense \& Educ. Fund, Inc., 753 F.2d I3I, I37 (D.C. Cir. 1985), cert. denied, 472 U.S. I02 I ( 1985 ). To prove laches, President Clinton would have to show that Jones delayed in asserting her claims, that the delay was not excusable, and that her delay unduly prejudiced Clinton. See AmBrit, Inc. v. Kraft, Inc., 8I2 F.2d I53I, I545 (IIth Cir. I986), cert. denied, 48I U.S. I04I ( 1987 ). Laches is not based "merely on time. Rather, laches is based upon changes of conditions or relationships involved with the claim." Farries v. Stanadyne/Chicago Div., 832 F.2d 374, 378 (7th Cir. 1987) (citations omitted). The laches period begins to run when the plaintiff discovers the facts that create her cause of action. See Coleman v. Corning Glass Works, 619 F. Supp. 950, 953 (W.D.N.Y. I985), affd, 818 F.2d 874 (Fed. Cir. 1987); see also Grant Airmass Corp. v. Gaymar Indus., 645 F. Supp. I507, 15 I5 (S.D.N.Y. 1986) (explaining that courts consider whether a plaintiff had actual or constructive knowledge of the relevant facts in determining whether a claim is barred from laches).

President Clinton's laches claim is buttressed by the lack of an explicit federal statute of limitations for Jones's civil rights claims; rather, federal law provides that state statutes and the common law should govern. See 42 U.S.C. \$ 1988 (Supp. V I993); $c f$. Nixon v. Fitzgerald, 457 U.S. $73 \mathrm{I}, 748 \& \mathrm{n} .27$ (1982) (distinguishing Nixon's case from one in which "Congress expressly had created a damages action against the President of the United States").

81 In Mackall v. Casilear, 137 U.S. 556 (1890), the Court opined:

The doctrine of laches is based upon grounds of public policy, which requires for the peace of society the discouragement of stale demands. And where the difficulty of doing entire justice by reason of the death of the principal witness or witnesses, or from the original transactions having become obscured by time, is attributable to gross negligence or deliber- 
tutional structure to impose an analogous duty on plaintiffs today to litigate (if possible) before a person's "death" as an ordinary citizen and "birth" as a President.

Historically, as an "equity" doctrine, laches did not apply to cases "at law" governed by explicit statutes of limitation. After the historic merger of law and equity in I938, however, those old distinctions should matter little here.82 Other formerly "equitable" defenses, such as estoppel and fraud, have long been allowed to defeat actions "at law";83 and the Federal Circuit, at least, has squarely held en banc that laches may be invoked to prevent strategic manipulation in a "law" case even if an explicit statute of limitation applies and has not run. ${ }^{84}$ In any event, even if the technical equitable doctrine of laches is unavailable, its underlying logic can apply when understood in light of the dictates of constitutional structure and packaged as a matter of constitutional common law. ${ }^{85}$

\section{The Venue Variant}

Even if constitutional structure and history are not strong enough to freeze a civil suit against a sitting President, they might be strong enough to influence where and how the suit unfolds. Disruption of the President's duties should be minimized. A good argument can thus be made that, if a sitting President may be sued for damages, suit should

ate delay, a court of equity will not aid a party whose application is thus destitute of conscience, good faith and reasonable diligence.

The time for this son to have attacked his father on the ground of fraud was prior to that father's death .... .

Id. at 566 (citations omitted).

82 See fleming James, Jr., Geoffrey C. Hazard, Jr. \& John Leubsdorf, Civil ProceDURE 430-3I (4th ed. I992) ("[A]n equitable defense or counterclaim may be interposed to an action presenting only legal issues or vice versa.").

83 Federal Rule of Civil Procedure 8(c) explicitly recognizes the affirmative defenses of estoppel and fraud, as well as of laches. FED. R. Civ. P. 8(c).

84 In A.C. Aukerman Co. v. R.L. Chaides Constr. Co., 960 F.2d ro20 (Fed. Cir. I992) (en banc), the court stated:

[Plaintiff] is in error in its position that, where an express statute of limitations applies against a claim, laches cannot apply within the limitation period. In other areas of our jurisdiction, laches is routinely applied within the prescribed statute of limitations period for bringing the claim.

$\cdots$

.[W]e are unpersuaded that the technical distinction between application of laches against legal damages and an equitable accounting which [plaintiff] asks us to draw should be made.

Id. at I030-3I (citations and emphasis omitted); see also Technitrol Inc. v. NCR Corp., 5 I 3 F.2d I I30, Ir30 (7th Cir. I975) (adopting the district court opinion in Technitrol Inc. v. Memorex Co., 376 F. Supp. 828, 83I (N.D. Ill. 1974), which applied laches to damage suits).

85 Once again, we need go no further than to recognize a Category Two presidential privilege that Congress may perhaps have power to modify. See supra p. 705. 
lie only in Washington D.C.: no other court should have personal jurisdiction or venue against an unconsenting ${ }^{86}$ sitting President.

Several things point this way. First, the language of Article III and of the Judiciary Act of 1789 provided that suits against foreign Ambassadors be tried in the original jurisdiction of the Supreme Court, which would of course sit in the nation's capital. ${ }^{87}$ The underlying logic here was geographic: ambassadors would operate out of the nation's capital, and suit in that city would minimize disruption of their duties. ${ }^{88}$ If foreign dignitaries enjoy this litigation privilege, should not the President a fortiori (at least in the absence of an express congressional statute to the contrary)?

Of course, our old friend expressio unius might argue that, if the Framers had meant for the President to enjoy an analogous venue privilege, they would have explicitly so provided in Article III alongside the Ambassador Clause. But perhaps the Framers were simply not thinking about the unusual case of a civil damage action against a sitting President. When they did think about suits against the President, they explicitly provided that impeachment trials would take place in the Senate, again in the nation's capital. The Federalist Papers explicitly emphasized the geographic logic that underlay this choice. ${ }^{89}$

Recall also Jefferson's obviously geographic concern that litigation in "the several courts" (note the plural) would "bandy [the President] from pillar to post, keep him constantly trudging from north to south \& east to west, and withdraw him" from the district and thus from "his constitutional duties." 90 Few at the Founding would have thought that any court on the continent could use newfangled longarm statutes to reach out and grab the President of the United States. ${ }^{91}$ Jefferson summed it up nicely, in words that also sum up nicely much of our overall argument:

As to our personal attendance in Richmond [at the Burr trial], I am persuaded the Court is sensible, that paramount duties to the nation at large control the obligation of compliance with their summons in this case; as

\footnotetext{
86 Venue and personal jurisdiction defenses are of course waivable. See FED. R. CIV. P. I $2(\mathrm{~h})(\mathrm{I})$.

87 See U.S. ConsT. art. III, § 2, cl. 2 ("In all Cases affecting Ambassadors . . . the supreme Court shall have original Jurisdiction"); Judiciary Act of 1789 , § I 3, I Stat. 73, 80 ( I 789 ) (declaring that the Supreme Court "shall have exclusively all . . . jurisdiction of suits or proceedings against ambassadors, or other public ministers").

88 See Akhil Reed Amar, Marbury, Section 13, and the Original Jurisdiction of the Supreme Court, 56 U. CHI. L. REV. 443, 469-78 (1989); Akhil Reed Amar, The Two-Tiered Structure of the Judiciary Act of 1789 , I38 U. PA..L. REV. I 499, I560 n.222 (I990).

89 See The Federalist No. 65, at 400 (Alexander Hamilton) (Clinton Rossiter ed., I96I).

90 See supra p. 7 I8.

91 Until the appearance of the 1945 "minimum contacts" language of International Shoe v. Washington, 326 U.S. 310,320 (1945), suits against D.C. officials were hard to bring because longarm jurisdiction did not exist. See Pennoyer v. Neff, 95 U.S. 7I4, 722 (I878).
} 
they would, should we receive a similar one, to attend the trials of Blennerhasset and others, in the Mississippi territory, those instituted at St. Louis and other places on the western waters, or at any place, other than the seat of government. To comply with such calls would leave the nation without an executive branch, whose agency, nevertheless, is understood to be so constantly necessary, that it is the sole branch which the constitution requires to be always in function. It could not then mean that it should be withdrawn from its station by any co-ordinate authority. ${ }^{92}$

\section{CONCLUSION}

In the end, we suggest that temporary immunity from arrest is the constitutionally preferable reading of executive immunity in many situations. This immunity, which essentially tolls cases against a sitting President, avoids the twin dangers of making all Americans pay for the President's sins and of putting Presidents above the law. Our "arresting" conclusion is that a proper judicial holding in Clinton's favor could limit rather than extend the mischief of Nixon.

92 Letter from Thomas Jefferson to George Hay, supra note 67 , at 232 . To be sure, improved transportation technology facilitates travel and makes long distance litigation infinitely more feasible than at the Founding; but why should the presidential mountain be obliged to come to plaintiff Muhammad rather than vice versa? Until Congress speaks clearly to the contrary, should not litigation against a sitting President accommodate his unique need to operate from the nation's capital, supervising the government, and attending to the people's business - at least if a plaintiff is responsible for the timing of a lawsuit and purposefully chooses to sue a President in session?

If the suit were brought in D.C., Jones's case may be dismissed. District of Columbia courts in such cases apply the District's statute of limitations, even if the underlying cause of action occurred elsewhere. See Steorts v. American Airlines, 647 F.2d I94, I97 (D.C. Cir. I98 I). However, Jones could argue that a transfer of venue motion will allow her to carry the Arkansas statute of limitations with her to Washington. If the reason for transfer of venue is based on forum non conveniens and 28 U.S.C. \$ $1404(\mathrm{a})$, she may be successful. See Van Dusen v. Barrack, 376 U.S. 612, 639 (1964). But if President Clinton phrases the argument in terms of personal jurisdiction and venue (as we suggest), the D.C. statute of limitations may be used: an Arkansas transferor court lacking personal jurisdiction and venue could not support transfer under Van Dusen, and transferee law would apply. See Paul M. Bator, Daniel J. Meltzer, Paul T. Mishkin \& David L. Shapiro, Hart \& Wechsler's The Federal Courts and The Federal System i 744-45 (3d ed. i 988); i5 Charles A. Wright, Arthur R. Miller \& EdWard H. Cooper, Federal Practice \& Procedure $\$ 3827$, at 26I-67 (2d ed. i986). The D.C. statute of limitations for intentional torts in violation of $\S_{1983}$, such as assault, is one year. See D.C. Code AnN. § I2-30I (4) (I993); Hobson v. Wilson, 737 F.2d I, 32 (D.C. Cir. I984) (distinguishing assault cases, which have a one-year statute of limitations, from First Amendment claims, which have a three-year limitations period), cert. denied, 470 U.S. I084 ( 985 ); Williams v. District of Columbia, 676 F. Supp. 329, 332 (D.D.C. I 987). The one-year limitation also includes actions for "libel." See D.C. CoDE ANN. § I 2-30I (4) (I993). 